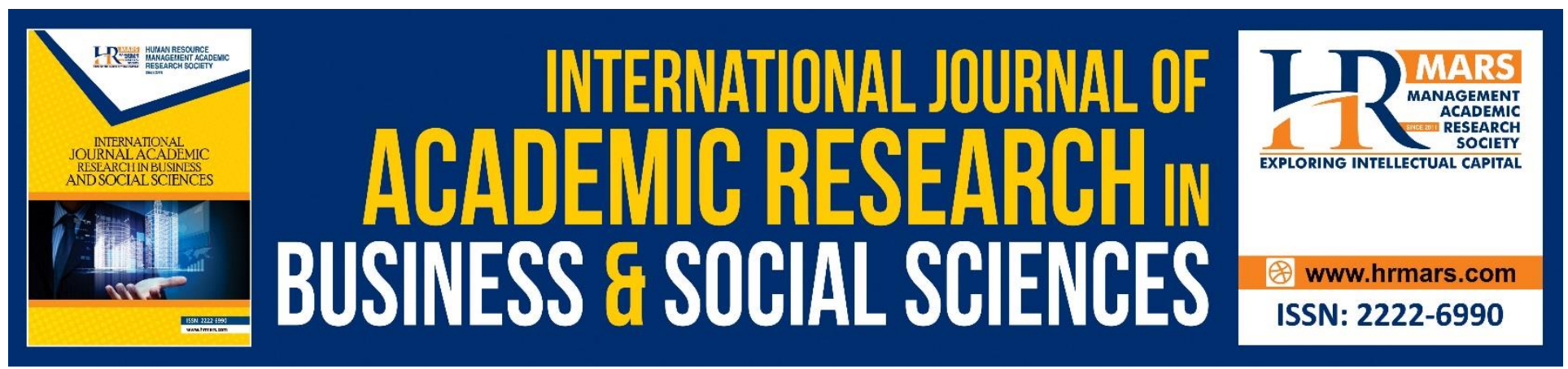

\title{
Women in Leadership Positions: Perspectives from an International Consulting Company
}

Anca VOICILĂ, Valentina Mihaela GHINEA, Adina FILCULESCU

To Link this Article: http://dx.doi.org/10.6007/IJARBSS/v8-i8/4457

DOI: $\quad 10.6007 /$ IJARBSS/v8-i8/4457

Received: 28 June 2018, Revised: 23 July 2018, Accepted: 29 July 2018

Published Online: 30 August 2018

In-Text Citation: (Voicilă, Ghinea, \& Filculescu, 2018)

To Cite this Article: Voicilă, A., Ghinea, V. M., \& Filculescu, A. (2018). Women In Leadership Positions:

Perspectives From An International Consulting Company. International Journal Of Academic Research In Business And Social Sciences, 8(8), 170-192.

Copyright: (c) 2018 The Author(s)

Published by Human Resource Management Academic Research Society (www.hrmars.com)

This article is published under the Creative Commons Attribution (CC BY 4.0) license. Anyone may reproduce, distribute, translate and create derivative works of this article (for both commercial and non-commercial purposes), subject to full attribution to the original publication and authors. The full terms of this license may be seen

at: http://creativecommons.org/licences/by/4.0/legalcode

Vol. 8, No. 8, August 2018, Pg. 170 - 192

http://hrmars.com/index.php/pages/detail/IJARBSS

JOURNAL HOMEPAGE

Full Terms \& Conditions of access and use can be found at http://hrmars.com/index.php/pages/detail/publication-ethics 


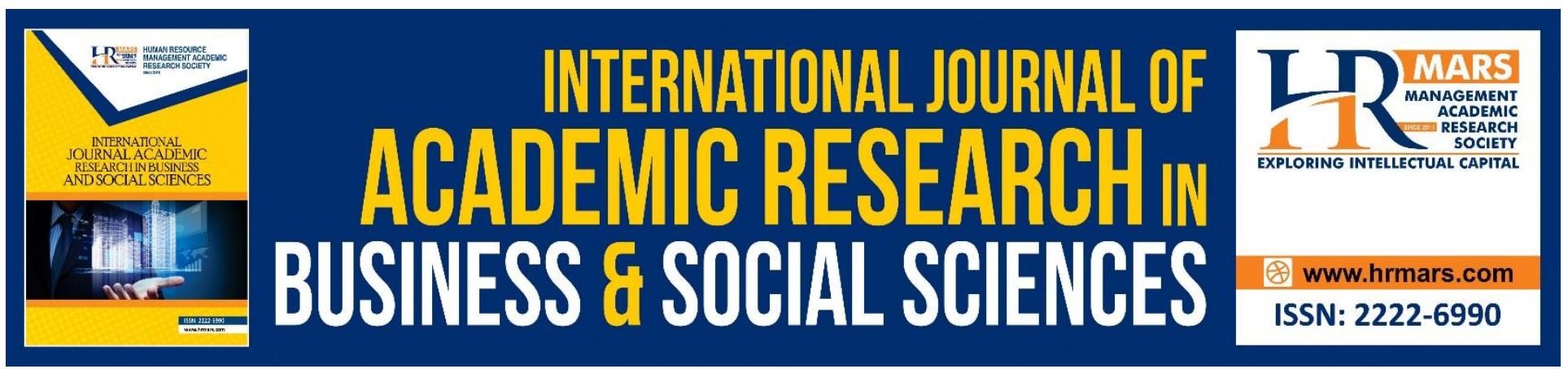

\title{
Women in Leadership Positions: Perspectives from an International Consulting Company
}

\author{
Anca VOICILĂ \\ Affiliation: The Bucharest University of Economic Studies \\ Email: voicilaancamaria@gmail.com \\ Valentina Mihaela GHINEA \\ Affiliation: The Bucharest University of Economic Studies \\ Email: valentina_ghinea@yahoo.com \\ Adina FILCULESCU \\ Affiliation: The Bucharest University of Economic Studies \\ Email: adinafilculescu@gmail.com
}

\begin{abstract}
In the last decades, academics, researchers and private and public organizations have demonstrated an increasing interest towards women in leadership roles. Without claiming to exhaust this interesting and current topic, this paper discusses the concept of leadership involved in multinational corporations from the perspective of gender equality in light of the current development of female leadership programs that have become the norm in all socially responsible businesses. The research is based on a case study of the effects of such a leadership development program implemented in an international accounting and consulting corporation with a subsidiary in Romania. Through a quantitative analysis based on a web survey, the paper analyses if the women in the corporation report having faced any particular barriers in their pursuit of management positions and if there are differences in the way in which female and male leadership styles are perceived. The main contributions of the paper are an assessment of the effectiveness of the selected leadership development program and a list of recommendations that can be followed by companies with similar leadership development programs in order to support women empowerment and advancement in the company.
\end{abstract}

Keywords: Leadership, Female, Gender Diversity, Career, Empowerment, Management

\section{Introduction}

Leadership is a really broad concept and there are various theories and styles of leadership. This is because leadership is deeply related to cultural beliefs and it evolves as these beliefs change. 
INTERNATIONAL JOURNAL OF ACADEMIC RESEARCH IN BUSINESS AND SOCIAL SCIENCES

Vol. 8, No. 8, August 2018, E-ISSN: 2222-6990 @ 2018 HRMARS

Nonetheless, leadership remains about three different elements: people, goals and influence. Leadership is people-driven meaning that it reflects the ability to inspire people helps to achieve the set goals of an organization (Daft, Kendrick, \& Vershinina, 2010). Thus, the leader's mission is to direct others to advance and to motivate people to achieve objectives through a certain way of acting. The different styles of leadership derive from different ways of motivating people, different kinds of goals and the nature of the organizations (Hannagan, 2008).

However, leadership is much more than authority or power because it is based on a certain level of voluntary support from group members. Leaders do not lead simply by directives but by persuasion, motivation and empowerment, by identifying and gaining engagement for a stimulating or challenging vision. Also, leaders not only manage individual performances, but also the performance of the group; and as a model of exertion of authority, leaders create an appropriate organizational context. Leadership demands a learning and adaptation strategy. A leader must engage and teach people to face challenges, adjust their values, change their outlook, and develop new forms of behaviour. The one who leads must always ask questions to be always prepared in any situation (Vasile, 2014). Thus, becoming a leader implies more than a leadership role, gaining new skills and shaping one's behaviour to the requirements of the role. It implies a significant change in identity.

In regards to women and leadership roles, the scientific literature has investigated whether females have the necessary qualities to be effective leaders (Rosser, 2003), whether women have better leadership skills than men (Eagly \& Carli, 2003) and what factors explain the reality that there are fewer women in leadership positions than men (Lammers \& Gast, 2017). Moreover, the concept of female leadership has been associated with the issue of human rights and the idea of equality between genders and the right of having the same chances on the labour market (Joshi, Neely, Emrich, Griffiths, \& George, 2015). However, the general outlook prevalent in the current literature is that there is a need to talk about feminine attributes of leadership style instead of female leadership and that organizations should seek to develop these attributes in all leaders irrespective of genders because these attributes have been shown to improve employee morale and productivity (Kim \& Shin, 2017).

In spite of some signs that we are finally starting to overcome stiff barriers that have prevented women from aspiring to top positions offered in global corporations, the fact remains that attaining corporate success is a very discouraging task for many women leaders in the Western world. In areas like finance, economics and investments, females continue to be sorely under-represented in processes of decision-making in organizations and institutions at international, global and national levels. For example, International Monetary Fund and World Bank have only 20\% women in their leadership staff and approximatively $10 \%$ women governors. On the other hand, some argue that women are advancing their careers faster in the governmental environment rather than in the private sector. Nearly $10 \%$ of Member States of the United Nations are headed by women, compared to $3 \%$ of the top 1,000 multinational companies, which are led by a president or chief executive female (Deloitte, 2012). Furthermore, women represent approximately $20 \%$ of all parliamentarians worldwide, compared to $13.5 \%$ women included in the management of the top 500 US companies (idem). In what regards Romania, a recent analysis showed that it contradicts international trends. If at the level of representation in the parliament, Romania is among the last five places in the world, ahead of Japan, Hungary, Turkey and Brazil (Gârboni, 2014), recently a research firm placed Romania on the 8th place overall for the percentage of women in top management positions of companies (Milligan, Levine, Chen, \& Edkins, 2014). 
INTERNATIONAL JOURNAL OF ACADEMIC RESEARCH IN BUSINESS AND SOCIAL SCIENCES Vol. 8, No. 8, August 2018, E-ISSN: 2222-6990 @ 2018 HRMARS

This paper analyses the results of a leadership development program implemented in an international accounting and consulting corporation with a subsidiary in Romania. After a review of the scientific literature regarding the barriers to women's advancement in leadership positions, the paper presents the result of a web-based survey developed specifically to measure the extent to which the women in the corporation report having faced any particular barriers in their pursuit of management positions in comparison to their male counterparts and if there are differences in the way in which female and male leadership styles are perceived in the company. The last section of the paper presents an assessment of the effectiveness of the selected leadership development program and a list of recommendations that can be followed by companies with similar leadership development programs in order to support women empowerment and career advancement.

Research of women in leadership roles in other countries, notably in East-European, postcommunist countries or countries with rooted traditions like countries in the Middle East, Asia and Africa, is viewed as a promising direction due to the fact that the environmental conditions in which businesses have developed were different than in the West. As there is a paucity of research on female leadership in these countries, the current study which explores the issues surrounding female employees' access to top management positions in Romania intends to establish the basis for the development of more in-depth analyses of the main barriers which are encountered by women looking to advance their careers and of the main factors which might contribute to greater gender equality. As the study is focused on the particular case of a multinational corporation from the finance sector with headquarters in Romania, the findings regarding the perception of female employees as leaders and the effectiveness of female leadership development programs are applicable to other cases which concern the transfer of human resources practices inside multinational corporations. Thus, the study brings an interesting contribution to the literature on female leadership by focusing on a geographical area which is currently understudied and also to the literature on the transfer of human resources practices by highlighting the main limitations of the leadership development program developed by the multinational corporation chosen for the case study.

\section{Barriers to women's advancement in leadership positions}

Numerous researches and surveys were conducted to demonstrate the favourable impact of women's existence at the top of companies, many of them concluding that women are more likely to possess effective leadership characteristics and have great performance in leadership positions (Kim \& Shin, 2017). Also, researches followed comparative studies on feminine and masculine leadership. Female leadership is usually defined by differentiating between masculinity and femininity. The attributes that are supposed to influence the achievement and the processes of decision making and problems solving are compared in order to define it. Some real differences were found in term of leadership characteristics between men and women due to the fact that they are biologically different and in most of the cases the culture and the society model or strengthen specific gender roles (Johnson, Murphy, Zewdie, \& Reichard, 2008).

With reference to strengths, it was found that women establish higher standards and are more open towards new or development. In addition, they are more ambitious (involved in solving issues and cooperating) and curious (they are more likely to execute) (Radu \& Năstase, 2011). They pay personal attention on subordinates and prefer to create a good work environment, so they could be considered more prone to experiment transformational leadership (Kim \& Shin, 2017). In contrast, men's style is instrumental, aiming attention on giving directions and they are therefore inclined towards transactional leadership (idem). With respect to areas of development, women are more 
INTERNATIONAL JOURNAL OF ACADEMIC RESEARCH IN BUSINESS AND SOCIAL SCIENCES

Vol. 8, No. 8, August 2018, E-ISSN: 2222-6990 @ 2018 HRMARS

exigent with themselves and less self-confident and this is why men value more business opportunities, making more profits (Radu \& Năstase, 2011).

When studying gender differences regarding leadership styles, nowadays emotional intelligence, collaboration and nurturance are significantly more important aspects than power or control. As a consequence of the new trends in international environment the feminine approach to management has become much more valued. Numerous studies were performed regarding emotional intelligence, and most of them, like that of Mandell and Phewnai (2003) demonstrated that females score more than men in this type of tests, making women more inclined to adopt a collaborative style of leadership. The previously mentioned authors also concluded that women have always wanted to lead a team but faced politically, socially and economically restrictions. This complex system of restrictions has been highly researched in the scientific literature under the name of the glass ceiling effect.

The literature provides many definitions of glass ceiling, some of them quite general and with a lack of analytical precision. Nevertheless, the glass ceiling has some characteristics recognized by most researchers. It leads to differences and inequalities which cannot be justified by characteristics of employees' work like capabilities, performance, motivation, experience and education, but only by referring to workers' gender. Also, inequalities generated by the glass ceiling increase exponentially with the hierarchical position (the higher the aspiring level, the more difficult it is for a woman to penetrate the glass. The glass ceiling can be encountered further or nearer the top of an organization, subject to national or organizational culture, but irrespective of these variances, the reality is that women are still the majority of workers in low skill low paid jobs (Blau \& Kahn, 2016). Even though in the last two decades the percentage of women interested in their career increased (both the number of women enrolled in different forms of education and the average marriage age), the change in people's psychology and perceptions is not reflected in the percentage of females succeeding in reaching higher positions in companies (Kim \& Shin, 2017). Usually, females' way to top-management positions is constrained starting with the moment they are recruited in the organization in non-strategic departments (human resources, office management or public relations) because they are not considered for recruitment in management positions. This is happening in spite of the realization that women are able to make effective leaders especially because they are more oriented towards developing, inspiring and motivating other employees, building relationships, collaborating and working in teams than men (Radu \& Năstase, 2011).

The main question which remains is why there are differences between the number of men and women in leadership roles. For this, the literature provides a series of answers. First of all, one explanation is related to the education received during childhood. In many families, girls are supposed to be passive and reticent to risk, while the boys are encouraged to pursue their objectives (Antecol, 2001). However, it is proven that a series of feminine qualities are needed for leading people: social skills, attention to people and relationships. While girls tend to underestimate themselves, boys tend to overestimate their potential and this diminished self-confidence exists even for the grown-up women (Radu \& Năstase, 2011). Thus, for a similar position, a woman salary is lower than a man's simply because they are afraid to demand for more (Blau \& Kahn, 2016).

Another explanation is that society itself developed a preconception regarding the maleness of leadership. Researchers argue that gender stereotypes and differences in entrepreneurship and business performance are reflected by men's and women's attitude toward competition and risk aversion, but also toward employees' management and business organization and that these differences may be innate or learned (Harrison, Leitch \& McAdam, 2015). Other researchers argue 
that the differences in attitudes concerning business justify why females are less expected to become entrepreneurs and the reason why, even if they do, males are likely to outperform women in their companies' investment and growth (Eddleston, Ladge, Mitteness, \& Balachandra, 2016). Traditional females' roles and stereotypes tend to influence women's viewpoint of their capabilities and undermine their efficacy and potential, especially that for growing their business (Dean \& Ford, 2017). Studies have shown that most personal characteristics do not influence entrepreneurial behaviour differently in the case of women and men, except for the individual perceptions of one's abilities, likelihood of failure and the existence of opportunities (Shirokova, Osiyevkyy, \& Bogatyreva, 2016).

Furthermore, it might be the case that women find senior leadership roles less appealing than men do. A McKinsey report showed that a greater job title did not represent a strong aspiration for women (Devillard, de Zelicourt, Sancier-Sultan, \& Kossoff, 2016). This is because of the importance that they give to work-life balance and particularly to motherhood, which outweighs the leadership opportunities organizations offer them. It was proven that females prefer a profession that offer them the possibility to deal with their personal life, but, in the same time, is fulfilling, they should be proud of and represent their identity. Also, they tend to prioritize family over work and choose a balanced lifestyle rather than career progression.

Finally, women usually have the perception that they are not able to be successful in leadership roles. This perception is explained by several factors. Most of them believe that it is not possible for them to be successful because they face more obstacles than men (ex. organizational culture or work-life priorities) (Newman, 2016). Some organizations do not support gender parity, representing a real obstacle for women career. In these companies, hiring and promoting processes favour men and adopt inflexible working program that affect women who tend to accept more family duties than men (Fernandez \& Campero, 2017). Also, because in many organizations few females play a role model at management level, this serves, at first sight, as proof that there are few opportunities for women (Derks, Van Laar, \& Ellemers, 2016). The first instinct when analysing an organization's hierarchy is that if other women tried and did not succeeded, no women will have chances. Even if there is no opportunity or is just a perception, this evidence is a discouraging impediment. The existence of these organizational barriers, coupled with the beliefs and values exposed by the environment in which females are socialized is what makes corporate female leadership development programs an important step towards the achievement of a gender equal labour market (Brue \& Brue, 2016).

\section{Research Methodology}

To investigate the barriers to female leadership and the impact of leadership development programs, this research is based on a quantitative study of a leadership program developed in an international accounting and consulting company which operates in Romania. The company has been present in Romania for more than 25 years and it has offices in several major cities including Bucharest. The company provides services in the following areas: audit, consulting, tax consulting, legal, financial, risk management and it currently employs more than 600 national and expatriate specialized professionals offering services to approximatively 3.500 clients from all the principal industries.

The company was chosen specifically because of its leadership development programs for women. As the company's employee profile is predominantly female (70\%), the company launched several campaigns aimed at empowering and recognizing the value of its female employees. Thus, 
the company designed an internal marketing campaign on Facebook and Linkedln which featured personal stories and advice for young people from female managers and also created a complex leadership development program to ensure that women's advancement to senior management levels is not incumbered by any gender barriers. According to the HR manager, this program includes sessions for career planning for female leaders, debates about work-life balance, motherhood and parenting and other issues which might impede women's career advancement in the company, Women's day events and other social events for networking with other female leaders in Romania.

The research was conducted in spring 2017 and started from the premise (hypothesis) that women in the selected company are treated equally in relation with men both regarding the payment and the support to advance in their career. The main research instrument was a survey which included 17 questions divided into two parts: (a) questions regarding personal information (year of birth, gender, professional status) and (2) questions referring to women leaders' position on the Romanian market and the perception on women leaders in the chosen company. The survey was sent via Google Forms to 100 employees from the following departments: Risk Advisory, Audit, Tax and Financial Advisory. The four named departments account for about 350 employees. 64 of the employees responded, representing $18 \%$ of the total number of employees and $64 \%$ of the employees who received the questionnaire. The questionnaire contained dichotomous questions, Likert scales, comment/essay box questions, multiple choice questions and matrix questions. For the questions referring to the differences between the perception of female and male leadership the authors have used the "Checklist of Admired Leaders" designed by Kouzes and Posner (2002) which proposes 10 essential characteristics to describe a leader (i.e., competent, confident, strategic planner, oriented towards the future, stimulative, honest, ambitious, with team spirit, persuasive, good communicator).

The gathered answers were processed using the Google Forms functions and exported into an excel file and then interpreted using several criteria.

The research hypotheses are:

H1: There are gender differences when valuing females' and males' leadership style in the company;

H2: One average males and females are not aware of the initiatives the company takes to promote the advancement of women in the company;

H3: The initiatives of the company's leadership concerning women empowering are not perceived as effective.

The objective of the research was to present the perception of representatives of both genders on leadership in the company (comparative perceptions on leadership). The research will answer the question: are employees able to see the strengths of women as managers by accepting their way of thinking as well as the strategies they apply to promote themselves in the "world of men"?

\section{Research Results}

Regarding the demographics of the sample, an analysis of the year of birth shows that the age range is quite large as one of the respondents was born in 1967 and one in 1995. However, most of the respondents fall within the age range between 32 years (four respondents born in 1985) and 23 years (five respondents born in 1993). Most of the participants to the survey are born in 1990 (11 respondents). 


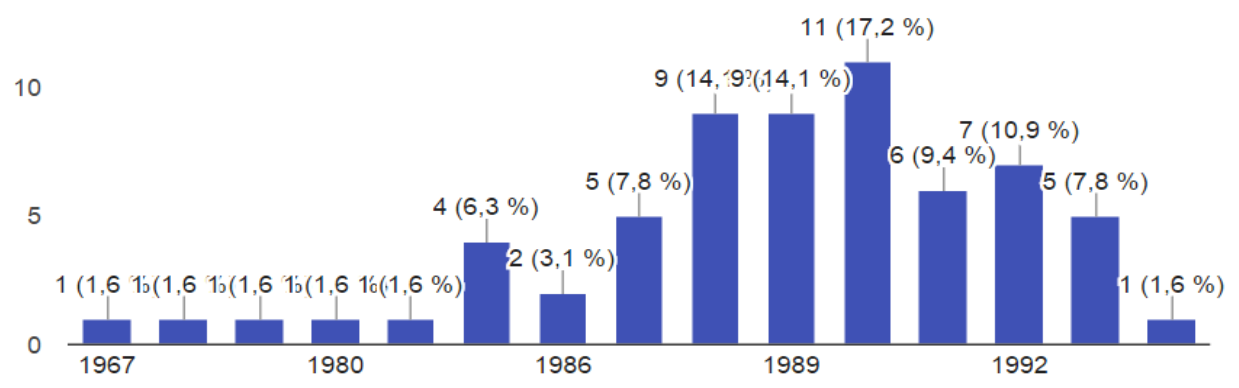

Figure 1. Respondents' year of birth

Source: Authors' research results.

Moreover, out of 64 respondents, $64 \%$ of them are women and $36 \%$ are males. Data obtained also showed that 14 respondents are managers or above, while 49 respondents do not hold a manager position. As described in the Table 1, out of the 14 managers, 7 are women and 7 are men. The 49 non-manager respondents are divided into 34 women and 16 men. The structure of the respondents is balanced considering the purpose of the analysis, mostly because it is important to discover women's perception concerning the treatment from which they benefit from the company.

Table 1

Gender and position in the company for the sample

\begin{tabular}{|c|c|l|}
\hline No. of respondents & Gender structure & Hierarchical structure \\
\hline \multirow{4}{*}{64} & \multirow{4}{*}{$\mathbf{4 1}$ women } & $\mathbf{7}$ manager/director \\
\cline { 3 - 3 } & & 34 non-manager \\
\cline { 2 - 3 } & \multirow{2}{*}{$\mathbf{2 3}$ men } & 7 manager/director \\
\cline { 2 - 3 } & & 16 non-manager \\
\hline
\end{tabular}

Source: Author's research results.

Next, we sought to identify the level of opinion of the respondents in regards to the existence of an adequate legislation in Romania for equal opportunities for women to men on the labour market. Thus, as shown in Figure 2, among the respondents, 34 persons do not know if there is any legislation on the matter and out of the rest, 29 respondents consider that the legislation is adequate, while 13 persons appreciate that improvements should be made.

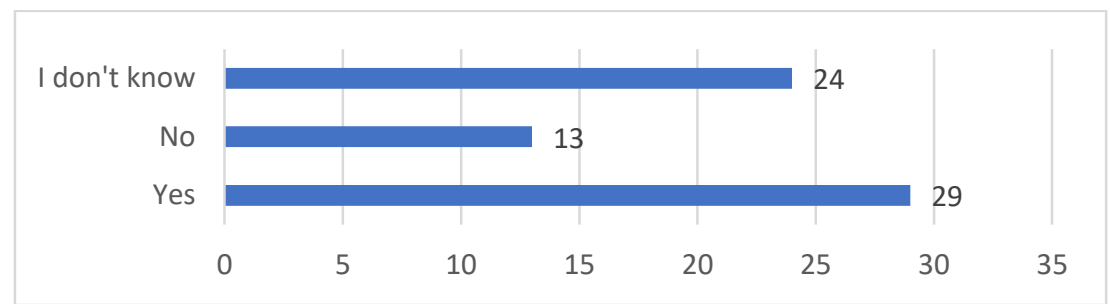

Figure 2. Opinion on the existence of adequate gender equality legislation in Romania Source: Authors' research results. 
INTERNATIONAL JOURNAL OF ACADEMIC RESEARCH IN BUSINESS AND SOCIAL SCIENCES Vol. 8, No. 8, August 2018, E-ISSN: 2222-6990 @ 2018 HRMARS

Out of the 13 persons that voted for the negative option, only two men consider that the legislation is not adequate, being considerably overwhelmed by 11 women who consider that current state laws do not adequately support gender equality on the labour market. Regarding the affirmative answer, out of 29 respondents, the votes were more balanced: $65 \%$ women and $34 \%$ men.

The imbalance is maintained also for the following question which evaluated the level of knowledge about the barriers faced by women regarding career advancement at the workplace compared to men. As shown in Table 2, out of 64 responses, 30 employees consider that women face greater barriers than men, 26 believe the contrary and 9 do not know how to answer. Interestingly, considering the respondents position within the company, only 6 managers/directors consider that women face greater barriers in the workplace, the gender proportion being equally distributed. Moreover, a greater number of non-manager women appreciate that they need to overcome more barriers than men do: 20 women out of 23 non-manager respondents chose the positive answer. Also, there are 3 men out of 4 manager employees who consider that a man and a woman face the same barriers on the labour market, while 13 female and 8 male non-managers have the same opinion.

Table 2

Women barriers - gender distribution

\begin{tabular}{|c|l|l|}
\hline Answer & No. of respondents & Gender structure \\
\hline \multirow{2}{*}{ Yes } & \multirow{2}{*}{30 respondents } & 6 men \\
\cline { 3 - 3 } & & 24 women \\
\hline \multirow{2}{*}{ No } & \multirow{2}{*}{26 respondents } & 12 men \\
\cline { 3 - 3 } & & 14 women \\
\hline
\end{tabular}

Source: Authors' research results.

Next, we measured the opinion of the respondents in regards to the support that the leadership of their company offers to women looking to advance their careers. As shown in Figure 3, none of the participants consider that the company is not supporting women.

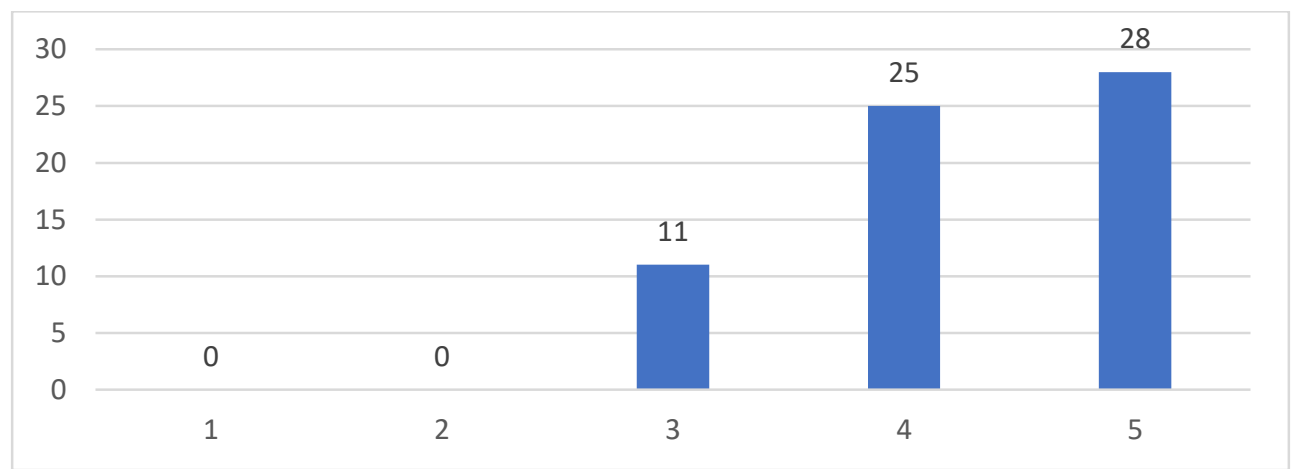

Figure 3. Extent of leadership support for women's career advancement (1- no support, 5- high support)

Source: Authors' own research results. 
INTERNATIONAL JOURNAL OF ACADEMIC RESEARCH IN BUSINESS AND SOCIAL SCIENCES Vol. 8, No. 8, August 2018, E-ISSN: 2222-6990 @ 2018 HRMARS

All the answers range between "to some extent" and "to a great extent". 11 persons consider that the company is helping women to achieve leadership roles to some extent, 25 to a large extent, while the majority appreciates that the support is offered to a great extent. All of the 8 women considering that the leadership is supporting females to some extent are non-manager employees. Moreover, out of 28 persons observing great support from the company for women, 13 are nonmanager females, 4 are manager females, 8 are non-manager males and 3 are non-manager males.

As the greatest issue on the market is related to unequal payment of men and women, the problem was measured also within the chosen company. As Figure 4 shows, even if 14 do not know the other colleagues' level of salary (for various reasons: the salary is confidential, they are not interested in the level of remuneration of others, etc.), 41 believe that the payment is fair. However, there are 9 respondents who state that in the company a woman wins less than a man for the same level of training and function.

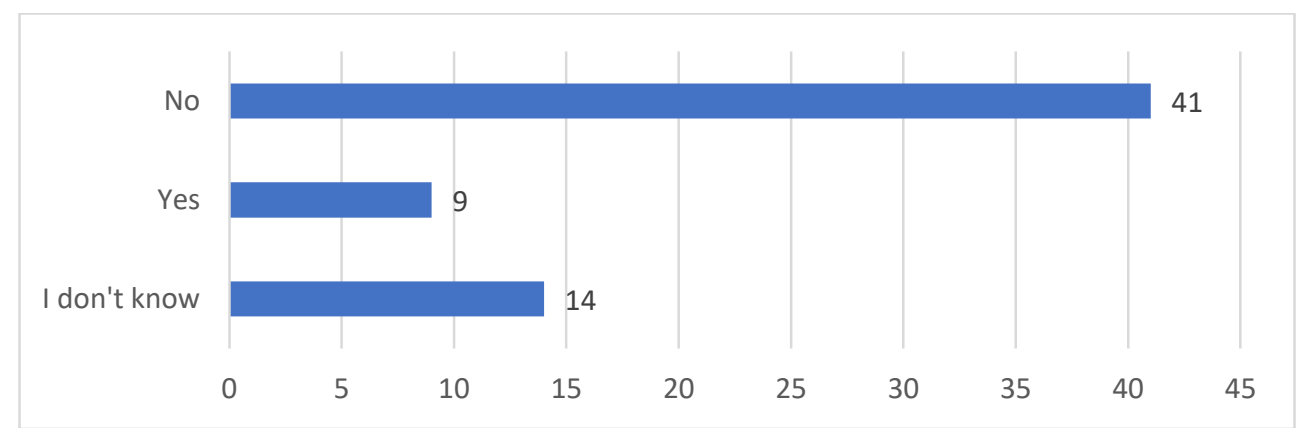

Figure 4. Opinion on the existence of equality of pay between men and women at the company Source: Authors' own research results.

On further analysis, it was noticed that 6 out of the 9 employees who voted "No" are nonmanager employees, all women. In addition, there is only one man, a manager/director, who chose the same option. The affirmative answer was selected by 25 women, mostly non-manager, and 16 men, mostly non-managers.

Strongly linked to remuneration is the fair promotion in leadership position. As we saw in other studies performed, it is generally considered that women have less chances to advance in career than men. As shown in Figure 5, in the selected company the most of the employees believe that the promotion is performed fairly and that there is no gender discrimination ( 55 persons). Still there are 7 persons ( 6 female non-managers and one male manager/director) who believe the contrary, that men occupy hierarchical functions faster than women, and unrelated to their merits. Moreover, the study found two persons who appreciate that promotions are made on other criteria (i.e., friendship), answer offered by a manager/director man, and a good relationship with persons on leadership position, answer given by a non-manager woman.

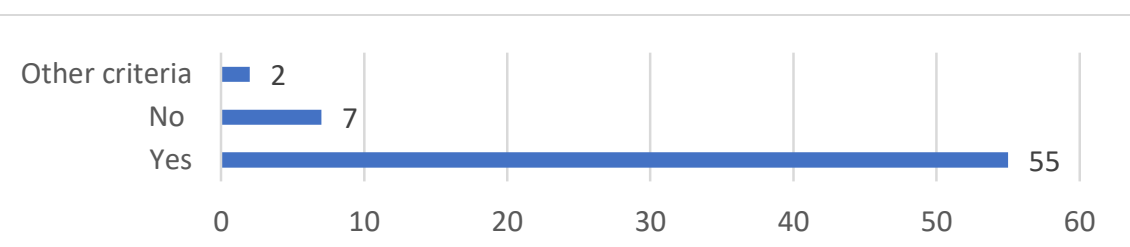

Figure 5. The opinion on the use of merit for promotion of both genders

Source: Authors' own research results. 
According to our survey, the majority of respondents think that there is a balance between their professional activity and the personal life (55 out of 64 as per Figure 6 ) and placed their answers between "to some extent" and "to a great extent". The gender structure is divided into 33 women and 22 men. Regarding the professional status, 11 out of 14 managers/directors and 44 non-manager employees out of 49 employees consider that they have a proper work-life balance. One nonmanager women believes that there is no balance between her professional and personal life, while 8 employees ( 1 men and 7 women) that there is a balance but only to a small extent.

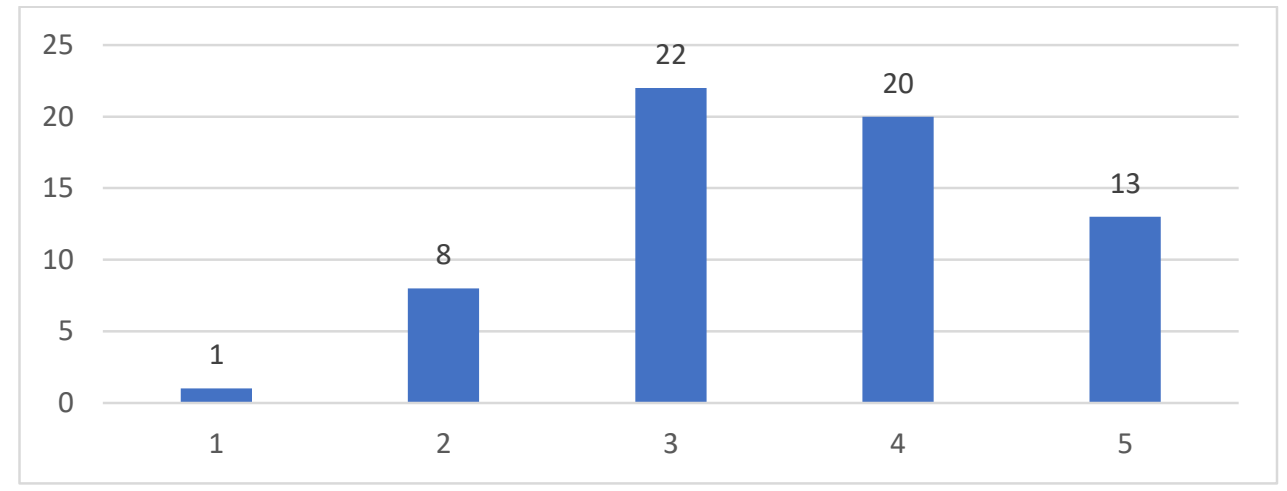

Figure 6. Balance between your professional activity and personal life (1- low, 5- high) Source: Authors' own research results.

Moreover, based on the overall responses, only two people have encountered work constraints in their personal activities: two non-manager women, while 21 respondents did not encounter any constraints (Figure 7). There are 10 women and 11 men sharing the same opinion. The distribution of professional status is represented by 4 managers and 17 non-managers.

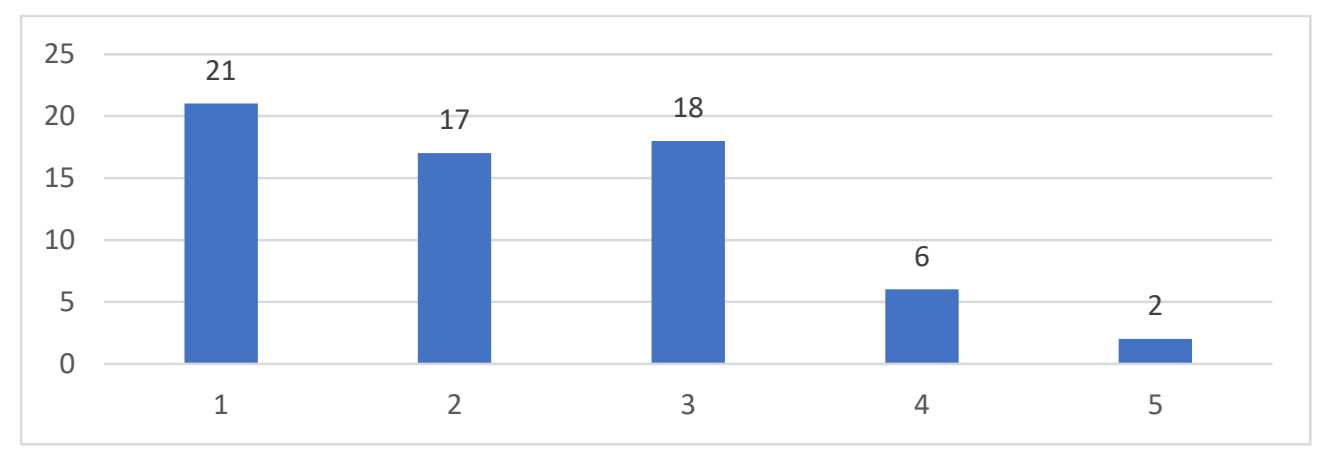

Figure 7. Constraints for personal activities (1-none, 5- many)

Source: Authors' own research results.

Furthermore, we have proposed a series of 10 leadership descriptors and asked the participants to range them according to their importance, from 1 (the least important) to 10 (the most important). The comparison based on the gender of the respondents is shown in Table 3 and that based on the hierarchical position is shown in Table 4. According to the responses obtained, there are only several characteristics that clearly belong to a certain gender, the others registering a similar score for both genders. The responses show that there are several leadership characteristics 
INTERNATIONAL JOURNAL OF ACADEMIC RESEARCH IN BUSINESS AND SOCIAL SCIENCES Vol. 8, No. 8, August 2018, E-ISSN: 2222-6990 @ 2018 HRMARS

associated with a particular gender, but that, in what regards the top three characteristics, there are no gender differences.

Table 3

Leadership descriptors based on the gender of the respondent

\begin{tabular}{|c|c|c|c|}
\hline $\begin{array}{c}\text { Respondent's } \\
\text { gender }\end{array}$ & Descriptor & $\begin{array}{c}\text { Male leaders } \\
\text { (mean) }\end{array}$ & $\begin{array}{c}\text { Female leaders } \\
\text { (mean) }\end{array}$ \\
\hline \multirow{10}{*}{ Female } & Competent & 7.63 & 7.93 \\
\hline & Oriented towards the future & 5.33 & 4.76 \\
\hline & Stimulative & 5.08 & 4.49 \\
\hline & Honest & 5.10 & 5.33 \\
\hline & Ambitious & 6.12 & 6.59 \\
\hline & With team spirit & 4.58 & 5.48 \\
\hline & Persuasive & 5.27 & 4.28 \\
\hline & Good communicator & 5.37 & 6.33 \\
\hline & Confident & 7.60 & 7.38 \\
\hline & With strategic planning skills & 7.02 & 7.05 \\
\hline \multirow{10}{*}{ Male } & Competent & 7.48 & 7.83 \\
\hline & Oriented towards the future & 4.70 & 5.35 \\
\hline & Stimulative & 5.62 & 5.30 \\
\hline & Honest & 5.96 & 5.45 \\
\hline & Ambitious & 6.39 & 6.76 \\
\hline & With team spirit & 4.67 & 5.33 \\
\hline & Persuasive & 6.05 & 5.32 \\
\hline & Good communicator & 5.36 & 6.00 \\
\hline & Confident & 8.35 & 8.43 \\
\hline & With strategic planning skills & 7.87 & 7.43 \\
\hline
\end{tabular}

Source: Authors' own research results.

Based on these results we can first of all conclude that the most prominent leadership

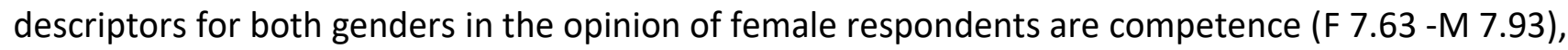
confidence (F 7.60 - M 7.38), strategic planner ( $7.02-M 7.05)$, and that these are the same as those for male respondents: competence ( $\mathrm{F} 7.48-\mathrm{M} 7.83$ ). confidence ( $\mathrm{F} 8.35-\mathrm{M} 8.43$ ) and strategic planner (F 7.87 - M 7.43). Furthermore, the analysis suggested that the good communicator, team spirit and orientation towards future are attributes associated to women's leadership style in the company, whereas persuasive and stimulative characteristics are attributed to the men's leadership style in the company.

Following the same reasoning, the analysis of managers and non-managers answers was performed. It was concluded that, confidence, competence, strategic planning and ambitiousness remain equal as in the case of the analysis performed by gender structure, the only difference being that competence is considered more important than confidence compared to the first analysis where confidence ranked the first. Moreover, when analysing the means in terms of manages and nonmanagers response, it was observed that, persuasiveness and stimulation were characteristics 
INTERNATIONAL JOURNAL OF ACADEMIC RESEARCH IN BUSINESS AND SOCIAL SCIENCES Vol. 8, No. 8, August 2018, E-ISSN: 2222-6990 @ 2018 HRMARS

attributed mostly to men and good communication and team spirit were mostly linked to women's leadership style, as per Table 4 below.

Table 4

Leadership descriptors based on the position of the respondent

\begin{tabular}{|c|c|c|c|}
\hline $\begin{array}{l}\text { Respondent's } \\
\text { gender }\end{array}$ & Descriptor & $\begin{array}{c}\text { Male leaders } \\
\text { (mean) }\end{array}$ & $\begin{array}{c}\text { Female leaders } \\
\text { (mean) }\end{array}$ \\
\hline \multirow{10}{*}{ Manager } & Competent & 9.14 & 9.57 \\
\hline & Oriented towards the future & 3.50 & 4.36 \\
\hline & Stimulative & 5.14 & 4.14 \\
\hline & Honest & 4.50 & 4.00 \\
\hline & Ambitious & 5.57 & 6.77 \\
\hline & With team spirit & 5.71 & 5.62 \\
\hline & Persuasive & 5.17 & 4.21 \\
\hline & Good communicator & 6.64 & 7.29 \\
\hline & Confident & 7.93 & 7.00 \\
\hline & With strategic planning skills & 7.86 & 7.29 \\
\hline \multirow{10}{*}{ Non-manager } & Competent & 7.14 & 7.41 \\
\hline & Oriented towards the future & 5.55 & 5.14 \\
\hline & Stimulative & 5.30 & 4.96 \\
\hline & Honest & 5.67 & 5.77 \\
\hline & Ambitious & 6.40 & 6.61 \\
\hline & With team spirit & 4.26 & 5.38 \\
\hline & Persuasive & 5.67 & 4.77 \\
\hline & Good communicator & 5.00 & 5.90 \\
\hline & Confident & 7.86 & 7.98 \\
\hline & With strategic planning skills & 7.18 & 7.16 \\
\hline
\end{tabular}

Source: Authors' own research results.

Our survey also revealed that women aiming to achieve a leadership position in the company have some skill gaps in areas such as negotiating, expressing their opinions and confidence. As presented in the theoretical part, these are the competences that are the strongest characteristics in the case of men leaders and the key features displayed by them. The greatest number of respondents agrees that women fighting to achieve a leadership position in the company should strengthen first their confidence (36 respondents out of 64). Next it was suggested that women need to develop their ability to express opinions, make decisions and think strategically. As shown in Figure 8 below, the least voted competence by the participants was project management, considered a skill already possessed which does not need to be improved by the women working in the company. 
INTERNATIONAL JOURNAL OF ACADEMIC RESEARCH IN BUSINESS AND SOCIAL SCIENCES

Vol. 8, No. 8, August 2018, E-ISSN: 2222-6990 @ 2018 HRMARS

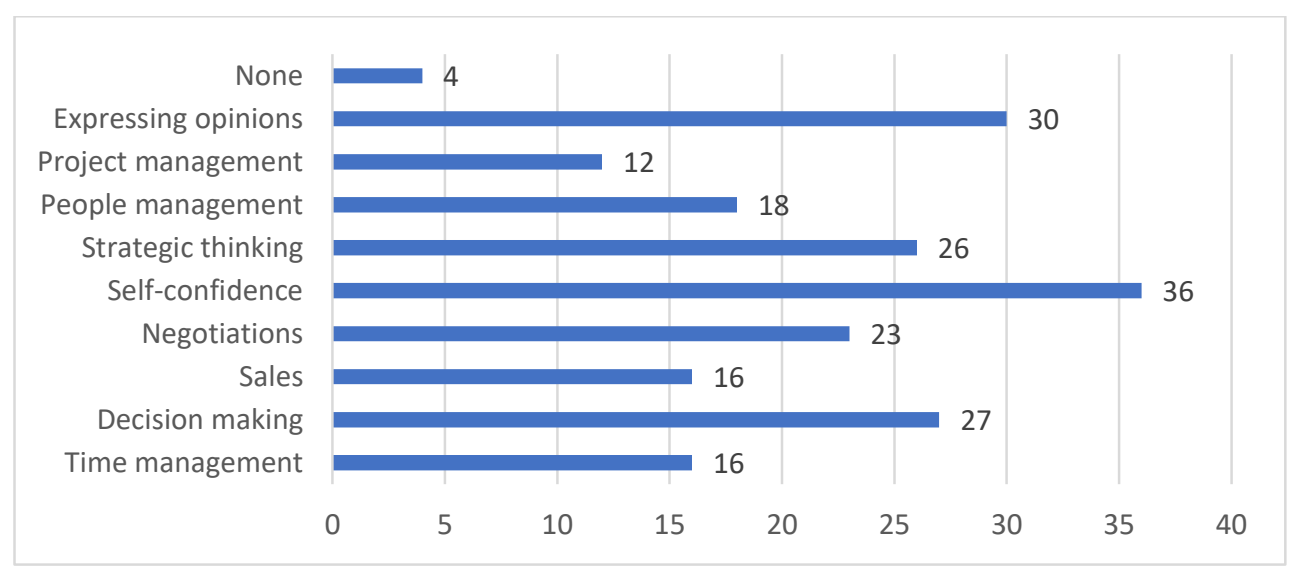

Figure 8. Competences that should be developed by women for leadership positions Source: Authors' Research Results.

The purpose of question number 16 from the survey was to highlight the perception about the knowledge and alignment of the company's initiatives to promote women's leadership roles within the company in Romania with those at the global level. As shown in Figure 9, the majority of respondents think that the Romanian subsidiary has aligned its practices to those proposed by the company at the global level. From 38 affirmative answers, $74 \%$ belong to women and $26 \%$ belong to men. Moreover, there are $71 \%$ non-manager employees giving the positive response and $29 \%$ managers. Nevertheless, there are still 22 employees (equally distributed between women and men) who are not aware of the company's initiatives in promoting women in leadership roles and three non-manager females who believe that the company's initiatives are not aligned to its global attempts and projects.

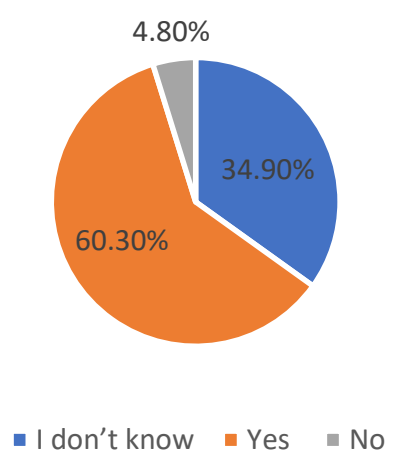

Figure 9. Alignment of gender equality initiatives in Romania with the global strategy of the company

Source: Authors' research results.

Through the last question of the survey, we discovered that the highest number of respondents believe that the undertaken measures for promoting women in the company are efficient. The results are shown in Figure 10. 
INTERNATIONAL JOURNAL OF ACADEMIC RESEARCH IN BUSINESS AND SOCIAL SCIENCES Vol. 8, No. 8, August 2018, E-ISSN: 2222-6990 @ 2018 HRMARS

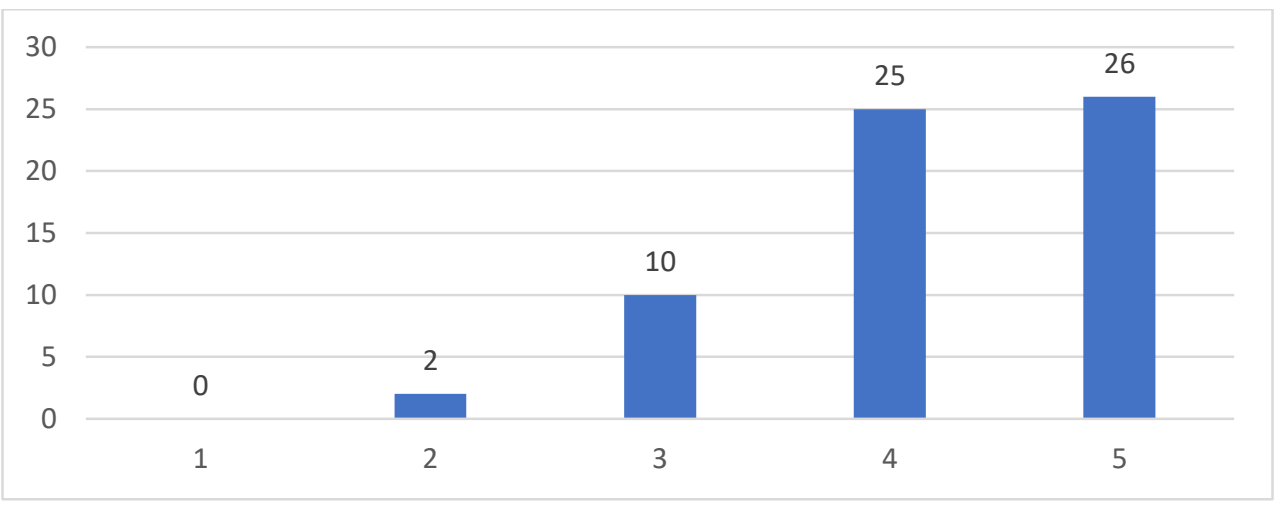

Figure 10. Effectiveness of female leadership development initiatives

Source: Authors' research results.

31 females and 20 males believe that the female leadership development initiatives in the company have been efficient to a large extent or to a great extent. Considering the professional status, the positive answers were distributed among 13 managers and 38 non-managers. We have found that none of the respondents consider that the initiatives inefficient, but there are still two non-manager females who appreciate that they are efficient only to a small extent.

\section{Discussion and Conclusions}

In order to conclude the research, the study's hypotheses are revised to validate if they were answered. The answers to the hypothesis represent the author's interpretation of the results, hence there could be another alternative too. The following table, Table 5, reveals the study's questions the results obtained through our quantitative investigation.

Table 5

Research hypotheses and findings

\begin{tabular}{|c|c|}
\hline Question/hypothesis & Finding \\
\hline $\begin{array}{l}\text { There are gender differences when valuing } \\
\text { females' and males' leadership style in the } \\
\text { company. }\end{array}$ & Yes, to a small extent. \\
\hline $\begin{array}{l}\text { The average of males and females within the } \\
\text { company are not aware of the initiatives the } \\
\text { company takes to promote the advancement } \\
\text { of women in the company. }\end{array}$ & $\begin{array}{l}\text { False. There are } 65.1 \% \text { respondents who know } \\
\text { about the company's projects and initiatives } \\
\text { and consider them either effective }(60.3 \%) \text { or } \\
\text { ineffective }(4.8 \%) \text {. }\end{array}$ \\
\hline $\begin{array}{l}\text { The initiatives of the company's leadership } \\
\text { concerning the women empowering are not } \\
\text { effective. }\end{array}$ & $\begin{array}{l}\text { False, there are } 96.8 \% \text { respondents who } \\
\text { believe that the initiatives are effective ( } 41.5 \% \\
\text { - to a great extent, } 39.7 \% \text { to a large extent and } \\
15.9 \% \text { - to some extent). Only } 3.2 \% \text { consider } \\
\text { that the projects were effective to a small } \\
\text { extent. Moreover, there are two participants } \\
\text { who consider that the promotion is made on } \\
\text { personal relationships criteria. }\end{array}$ \\
\hline
\end{tabular}

Source: Authors' own research results.

This study has allowed us to gather plenty of information concerning the women in leadership roles in chosen company. Overall, the research indicates a lower presence of females in leadership 
INTERNATIONAL JOURNAL OF ACADEMIC RESEARCH IN BUSINESS AND SOCIAL SCIENCES

Vol. 8, No. 8, August 2018, E-ISSN: 2222-6990 @ 2018 HRMARS

roles in the company, but both women and the company itself have been making strides to overcome the difficulties and improve the access of women to top leadership positions. Furthermore, the analysis allows us to outline the initiatives that the company should undertake in order to improve the gender balance at the top of the hierarchy and to progressively consolidate transformational leadership.

Firstly, the paper briefly outlined the initiatives that the company took to empower women. The company undertook a considerable number of projects to promote both women within the company and from other organizations. It started with an internal campaign supported by conferences, trainings, motivation materials and internal policies and established also a social club for women where they have the opportunity to develop their confidence and express opinions without being afraid to be judged by the others. Moreover, the organization actively participated in developing a series of reports on women leaders' condition in Romanian companies and institutions.

As a general overview of the findings, it is a very strong point that the company implemented a top-level of the hierarchy commitment to support female leaders within the organization and invested in mentoring and creating role models through their promotion campaign. It is well known the need for recognising that women empowering is integrated to future prosperity through developing a top-level commitment to simplify females' career path. There is an increasing number of organizations which make this type of commitment to females' leadership and which lay them out to firm's policies and procedures, including tackling unconscious gender biases in the workplace or in hiring practices and, like the company did, including formal mentoring programs. Nevertheless, as there are some exceptions on the responses obtained, concluding that some employees consider the practices ineffective or unfair and signal a lack of support from the leadership, several recommendations have been formulated in order to improve the gender equality practices.

Firstly, after reviewing the responses and considering the company management, we recommend a formal in-company training or coaching which shall present the current legislation in Romania concerning the equal chances on the labour market and non-discriminatory practices in the workplace. The recommendation is formulated due to a high percentage of employees who are not aware of the Romanian legislation on the subject (34.9\%) and their due rights.

Secondly, we recommend the leadership of the company to conduct an analysis on pay equity and asses the issue on a regular basis (suggested, at least yearly). The emphasis should be on total compensation, taking into consideration the fact that significand bonuses and rewards are offered at the end of each financial year. For a correct result, it is recommended to conduct a statistical approach, like multiple regression, not a simple average like payment by group or differences in averages because they could offer false negatives or false positives. A robust statistical analysis would ensure that all the legitimate differences in reward and payment are accounted: performance, experience, certifications and so on. Even if the company has a salary grid defined, the authors believe that each employee should have the opportunity to negotiate its salary at the promotion moment. The employees coming from outside of the company usually benefit from greater salary because they have the possibility to obtain easier the maximum limit of the grid through negotiation, while for the employees grown in the company from the beginning of their careers the growth is given by the first salary and the annual rate, which leads to non-uniform practices. Conducting such an analysis would enable the company to spend its compensation funds more wisely and pinpoint the unexplained payment gaps.

Thirdly, we recommend a review of the job structure as a part of the statistical approach. This would warrant that employees are classified into meaningful groups for comparison and that the 
pools are not too broad or too narrow. This delineation regarding the skills requirements linked to the job and allied responsibilities, would aid the company in ensuring that the remuneration for a specific job will be powered by its requirements, not by the gender distribution.

Finally, we recommend the implementation of a formal remediation process where an appointed and dedicated team will assess pay equity. The nominated team would oversee and conduct the assessment starting from identifying the groups that have unexplained pay gaps, conducting the analysis on specific employees, documenting the justifications for performing or not adjustments and ensuring that the identified adjustments are implemented. A responsible team with pay equity would improve the gender diversity outcomes.

For sure, the society, the legal institutions and the company itself could do numerous actions for women to be better represented in leadership position around the world or in the company. But, it is considered that we cannot just rely on society actions and norms. The study shows that any women that desires to reach a senior business leadership position should be determined, confident and make some sacrifices. Thus, we recommend women in the company aiming to achieve a leadership role to push themselves out of their comfort zone. Often, females self-select out of opportunities due to their impressions regarding what others expect from them or their comfort zone. As the survey results show, there are respondents that stated women need to increase their self-confidence and develop their ability to express their opinions more firmly. Thus, we recommend women the company to consider all networking opportunities which could be slightly out of each comfort zone.

\section{References}

Antecol, H. (2001). Why is there interethnic variation in the gender wage gap?: The role of cultural factors. The Journal of Human Resources, 36(1), 119-143.

Blau, F.D., \& Kahn, L.M. (2016). The gender wage gap: Extent, trends, and explanations. IZA Discussion Papers, No. 9656.

Brue, K.L., \& Brue, S.A. (2016). Experiences and outcomes of a women's leadership development program: A phenomenological investigation. Journal of Leadership Education, 15(3), 75-97.

Daft, R., Kendrick, M., \& Vershinina, N. (2010). Management. Andover: Cengage Learning EMEA.

Dean, H., \& Ford, J. (2017). Discourses of entrepreneurial leadership: exposing myths and exploring new approaches. International Small Business Journal, 35(2), 178-196.

Deloitte (2012). Deloitte Romania and Moldova. Retrieved from: www2.deloitte.com/ro/ro/pages/about-deloitte/articles/cxo-program.html.

Derks, B., Van Laar, C., \& Ellemers, N. (2016). The queen bee phenomenon: Why women leaders distance themselves from young junior women. The Leadership Quarterly, 27(3), 456-469.

Devillard, S., de Zelicourt, A., Sancier-Sultan, S., \& Kossoff, C. (2016). Women Matter 2016: Reinventing the workplace to unlock the potential of gender diversity. Retrieved from: www.mckinsey.com/ /media/mckinsey/global\%20 themes/women\%20matter/reinventing\%20the\%20workplace\%20for\%20greater\%20gender\% 20diversity/women-matter-2016-reinventing-the-workplace-to-unlock-the-potential-ofgender-diversity.ashx.

Eagly, A.H., \& Carli, L.L. (2003). The female leadership advantage: An evaluation of the evidence. The Leadership Quarterly, 14(6), 807-834. 
INTERNATIONAL JOURNAL OF ACADEMIC RESEARCH IN BUSINESS AND SOCIAL SCIENCES

Vol. 8, No. 8, August 2018, E-ISSN: 2222-6990 @ 2018 HRMARS

Eddleston, K.A., Ladge, J.J., Mitteness, C., \& Balachandra, L. (2016). Do you see what I see? Signaling effects of gender and firm characteristics on financing entrepreneurial ventures. Entrepreneurship theory and Practice, 40(3), 489-514.

Fernandez, R.M., \& Campero, S. (2017). Gender sorting and the glass ceiling in high-tech firms. ILR Review, 70(1), 73-104.

Gârboni, E.S. (2014). Women in politics during the Romanian transition. Procedia- Social and Behavioral Sciences, 163, 247-256.

Hannagan, T. (2008). Management. Concepts \& Practices. $5^{\text {th }}$ ed. New York: Pearson Education.

Harrison, R., Leitch, C., \& McAdam, M. (2015). Breaking glass: Toward a gendered analysis of entrepreneurial leadership. Journal of Small Business Management, 53(3), 693-713.

Johnson, S.K., Murphy, S.E., Zewdie, S., \& Reichard, R.J. (2008). The strong, sensitive type: effects of gender stereotypes and leadership prototypes on the evaluation of male and female leaders. Organizational Behavior and Human Decision Processes, 106(1), 39-60.

Joshi, A., Neely, B., Emrich, C., Griffiths, D., \& George, G. (2015). Gender research in AMJ: An overview of five decades of empirical research and calls to action. Academy of Management Journal, 58(5), 1459-1475.

Kim, S., \& Shin, M. (2017). The effectiveness of transformational leadership on empowerment: The roles of gender and gender dyads. Cross Cultural \& Strategic Management, 24(2), 271-287.

Kouzes, J.M., \& Posner, B.Z. (1995). The leadership challenge: how to keep getting extraordinary things done in organizations. California: Jossey Bass.

Lammers, J., \& Gast, A. (2017). Stressing the advantage of female leadership can place women at a disadvantage. Social Psychology, 48, 28-39.

Mandell, B., \& Pherwani, S. (2003). Relationship between emotional intelligence and transformational leadership style: A gender comparison. Journal of Business and Psychology, 17(3), 387-404.

Milligan, P.A., Levine, B., Chen, L., \& Edkins, K. (2014). When women thrive businesses thrive. Retrieved from: www.mercer.com/content/dam/mmc-web/Files/Gender-Diversity-Whenwomen-thrive-businesses-thrive-Mercer.pdf.

Newman, B.J. (2016). Breaking the glass ceiling: Local gender-based earning inequality and women's belief in the American dream. American Journal of Political Science, 60(4), 1006-1025.

Radu, C., \& Năstase, M. (2011). Leadership and gender differentiation. Review of International Comparative Management, 12(3).

Rosser, V.J. (2003). Faculty and staff members' perceptions of effective leadership: Are there differences between women and men leaders?. Equity \& Excellence in Education, 36(1), 71-81.

Shirokova, G., Osiyevkyy, O., \& Bogatyreva, K. (2016). Exploring the intention-behavior link in student entrepreneurship: Moderating effects of individual and environment characteristics. European Management Journal, 34(4), 386-399.

Vasile, C. (2014). Femei vs. bărbați în leadership - 'Glasul inimii' vs. 'Glasul minții'”. EcoStudent, 3, 6067. 
INTERNATIONAL JOURNAL OF ACADEMIC RESEARCH IN BUSINESS AND SOCIAL SCIENCES Vol. 8, No. 8, August 2018, E-ISSN: 2222-6990 @ 2018 HRMARS 